\title{
Treasure in the vault: the guardianship of 'heritage' seeds, fruit and vegetables
}

\author{
Abigail Wincott, University of Brighton
}

This is the accepted article, the final version of which is published in the International Journal of Cultural Studies (online October 4, 2017) doi.org/10.1177/1367877917733541. Reprinted by permission of SAGE Publications.

\begin{abstract}
Crop heritage is a growing global phenomenon whereby people conceive of change to agriculture in terms of loss, issuing calls to safeguard what remains for future generations. This article seeks to understand what it means to think about food and the politics of its production and consumption through the frame of 'heritage' by interrogating a prevalent metaphor of plants and seeds as 'treasure'. It argues the metaphor is more than decorative; it is strategic in producing certain conceptualisations of heritage value. While crop diversity is held to be important, and the great range of food plants a 'common heritage of humankind', the treasure metaphor is used in ways that impede the maintenance of that diversity, establishing seeds, plants and genes as precious materials best looked after by expert guardians in and secure 'vaults', 'banks' and walled gardens. Thus this particular conception of 'treasure' as a universal good actually plays an important role in legitimising and normalising the privatisation of crops heritage resources.
\end{abstract}

\section{Keywords}

Heirloom, heritage, crop conservation, alternative consumption, environmental humanities, biodiversity 


\section{An introduction to the heritage of crops and seeds.}

In the punishing cold of an Arctic mountain, in the remote Svalbard Islands, a doorway leads to what's meant to be the safest place on earth. Scientists are on their way, approaching through this isolated and hostile terrain and I'm with them as they carry a precious cargo of seeds to be kept out of the way of whatever climate change might bring. (BBC correspondent David Shukman reporting from Svalbard Global Seed Vault, 22 Jan 2016)

The TV reporter stands, muffled against the Arctic cold, in the icy interior of what looks like a nuclear bunker, 'deep inside a mountain' in 'the safest place on earth', built, he is told by an employee, to last 4,000 years. The 'precious cargo' he has accompanied up to the Arctic island is seeds and the genes they contain. He explains they are at risk from changes in modern agriculture, from war and natural disasters. Svalbard, with its rows and rows of metal shelves, stacked with boxes and packets of seeds from all over the world, represents 'a safeguard against the apocalypse'. Svalbard Global Seed Vault is the gene bank of gene banks, a secondary back up facility, storing spare seeds from the many secure storage facilities around the world. The Seed Vault has been reported on with relish by other journalists too, in stories which reproduce Svalbard's own narrative (and that of the Global Crop Diversity Trust, which funds it) of a precious heritage of humanity safeguarded in perpetuity, in a bleakly magnificent setting, thanks to military-style security.

The conceptualisation of seeds as 'precious' and the suitability of their storage in a high security vault is not inevitable however, nor is it uncontested. Opponents have argued that securing the gene pool for humanity's future food supply in closed gene bank facilities is both unjust and ineffective_-privatising resources developed over millennia by farmers and inadequate to the task of maintaining or growing diversity in the fields, where it is needed, something that informal seed saving is well equipped for (Fowler \& Mooney, 1990; Mulvany \& Berger, 2002; Nazarea, 2005; Phillips, 2016). This article examines the role of the metaphor of heritage as treasure in reproducing this situation. It produces particular conceptualisations of heritage value and certain materials, structures and relationships of conservation. The article also explores how the metaphor is variously adopted and challenged, as the crop conservation project is taken up by new interest groups.

\section{Investigating the politics of heritage crop discourse}

The discourse of crop heritage started to take shape in the early decades of the twentieth century, as botanists and experts in the newly ascendant field of agronomy had begun collecting and recording varietal and trait diversity in crop plants, for utilisation in crop breeding (Loskutov, 1999, p. 1). This work led to a consciousness among scientists that farms were increasingly modernising and adopting fewer, genetically less diverse varieties, in place of traditional, local ones. From the 1960s, agricultural science experts defined a global strategy for the conservation of crop plants as a gene pool for future crop improvements (Scarascia-Mugnozza \& Perrino, 2002, p. 2-5). The active organisation of this interest group led not only to the expansion of crop heritage discourse, but fixed it as a primarily scientific and agricultural issue. The growth of gene banks and genetic engineering for agriculture have led to seed companies focusing increasingly on genes rather than plants and the foods they become (Kastler, Onorati, \& Brac, 2013). Ex situ genebanks have assumed crucial importance in modern plant breeding and parallel efforts to maintain biodiversity, and their growth thus has significant economic implications (Breen, 2015, p. 43). 
It is not within the remit of crop science to critically examine the work of the discourse of heritage and of conservation, and there is a lack of reflexivity about the nature of the crop conservation project. However there have been interventions from increasing numbers of sociologists and anthropologists. Fowler and Mooney ${ }^{1}$ (1990), Friis-Hansen and Sthapit (2000), Nazarea (1996, 1998, 2005, 2006) and Breen (2015) have all addressed issues of access and power in the conservation and management of 'plant genetic resources'. They have often done so through work with indigenous farmers in various parts of the world where industrialised agriculture has made inroads, but still operates alongside older ways of producing food. These anthropological and sociological interventions speak to the field of agricultural science and maintain that frame of reference. Crop heritage is thought of as genetic resources for conventional agriculture, which may be managed and owned, though these authors question assumptions about who is entitled to do so and in some cases critique the concepts underpinning conservation discourses (Breen, 2015; Graddy, 2013). They also have a tendency to focus on the global South, where traditional crops remain part of agricultural production, rather than wealthier countries, where heritage crops are associated with eating out, home leisure gardening and heritage visitor sites, meaning the politics of this newer consumer-oriented heritage discourse have been neglected.

The discourse of heritage vegetables is both global-as some of the interest groups organise themselves across borders, and the same ideas and claims crop up in different parts of the world-and locally variable. This paper takes the UK context as its focus. It is one that has received little attention, a relative late-comer to the popular discourse of heritage vegetables and seeds as a consumer good and form of activism. But at the same time local British iterations of heritage vegetable discourse connect with and build on global networks of activists, retailers and genebanks. The central arguments about what it means to think about our food system through the frame of heritage have resonance around the world, wherever government agencies, campaigners, researchers and journalists seek to promote crop biodiversity and indeed cultural diversity of our food systems through the idea of 'heritage'.

The literature critiquing the practices of the 'crop genetic resources movement' has not questioned the use of heritage as an organising concept. In the agricultural science sector, there are frequent references to endangered crops as a heritage of humankind, to be safeguarded for future generations. In the UK, the term 'heritage' vegetables will be familiar to many consumers, seen on seed and produce packets, in magazine features and in show gardens. The tendency in North America is to use the term 'heirloom' (Jabs, 1984; Jordan, $2007,2015)$, with its connotations of something personally meaningful, handed down in the family. This is perhaps reflected in the small number of academic works on the subject that take a cultural approach (Carolan, 2007; Jordan, 2007, 2015), where personal connections between people and the seeds and vegetables they collect and conserve are stressed and in Jordan's case, the subject is viewed through the lens of memory. It is hard to know how much the term 'heritage', in use in the UK, impacts on how the issues are conceptualised, but certainly Britain has a longstanding and extremely active heritage conservation culture. Everything from castles to factories has been protected from demolition and change and

\footnotetext{
1 Cary Fowler, whose background is in sociology, has an interesting relationship with the agricultural research sector, both critiquing some of its practices and working closely with its major institutions, including the UN FAO and CGIAR, and helping to establish the Svalbard Seed Vault.
} 
foods are merely the latest object of heritage concern. The discourse of heritage has a tendency to grandiloquence and a focus on the material 'stuff' of the past, rather than its meanings or practices (Smith, 2006). This article is examining a global heritage discourse, but by focusing on the UK context may well reflect that country's particular heritage culture.

Existing UK heritage conservation bodies have apparently seen saving heritage vegetables and fruit trees as a natural extension of their remit. The National Trust is large heritage conservation organisation managing around 400 historic sites (National Trust, 2012). It has opened many collections of heritage vegetables in historic kitchen gardens in the grounds of its stately homes, as well as heritage orchards, as has its Scots counterpart, the National Trust for Scotland. Specialist heritage bodies such as the Heritage Seed Library (operated by charity, Garden Organic) and smaller local heritage orchards and gardens have aped the National Trust's envied membership and entry-fee schemes, and there are now many heritage gardens and orchards across the country. Here, visitors can not only view the heritage as it grows, but often also buy it in on-site shops, restaurants and garden centres.

At the same time as this expansion of heritage visitor sites, the idea of crop heritage has been central to the work of many activist groups seeking radical social and economic change to the food system; groups like Reclaim the Fields, La Via Campesina and the Landworkers' Alliance are active in the UK. The posters, websites and leaflets produced by these groups argue that heritage crops are threatened by corporate capitalism, and to grow them and swap seeds is to resist corporate dominance of our food system. This activist discourse of heritage vegetables and seeds finds its way into the lifestyle media, where journalists report on a consumer-led movement to reclaim lost tastes and pleasures, once enjoyed by our grandparents, but now threatened by the bland 'industrial' produce offered by supermarkets (Wincott, 2015, p. 581).

From reports by the UN FAO to the Guardian lifestyle pages via the National Trust tearoom and anti-capitalist posters, it is clear the discourse of heritage vegetables does a lot of different work for a lot of very different interest groups. There are some troubling contradictions immediately apparent in these newer discourses of crop heritage. For example, many webpages and newspaper articles suggest that the growing and eating of heritage crops represents a resistance to the damaging dominance of big business and the profit motive over our food system. Yet major UK supermarket chains proudly announce heritage vegetable and fruit products in their stores, and where they are for sale, 'heritage' seeds, fruit and vegetables are associated with premium product lines and upmarket dining. Secondly, despite widespread claims that traditional seeds are a universal heritage of humankind, seeds and plants are now not only protected in closed genebanks but increasingly in the heritage gardens of stately homes. Thus heritage vegetable discourse may protect valuable cultural and material resources but also exclude the majority from their enjoyment, through processes of privatisation and commodification. Cultural studies has an important contribution to make to these debates, in unpicking or teasing out some of the contradictions or tensions, including popular culture in its scope, as well as formal agriculture and development policy making and placing the political nature of discourses centre-stage.

In order to understand the politics of heritage crop discourses, linguistic analysis forms a central part of my analysis. But practices, alliances and the role of various non-human entities are also considered as discursive (Laclau \& Mouffe, 2001, p. 109). These entities afford certain discursive possibilities and preclude others, and thus have agency, but it is not the materials which are the focus of analytic attention, but the human social relations they 
are used to shape. My aim is to understand how people employ heritage crop discourse in ways that structure the meanings and uses of seeds and food. This discourse constrains possible understandings and as it does so enables the creation of new kinds of value (Foucault, 1970, 1972, 1977) and a whole set of practices or fields of knowledge, from crop conservation in genebanks to the sale of luxury heritage tomatoes in supermarkets. I consider too the ways human interest groups seek to stabilise those particular meanings and the value they produce, by enrolling materials, from garden walls to seed packets, to the ice of Svalbard (Latour, 1986, 1991; Law, 1991). The discursive field is where a battle is played out, to determine the value of resources and to secure access to that value while limiting the access of others.

The current article reports on one aspect of a larger project which investigated the organising concepts of heritage vegetable discourse, mapped the field of social actors engaged with crop heritage and examined the kinds of power relations which these social actors negotiate through the language, images, practices and structures of heritage vegetable discourse. I have over the course of this work gathered around 500 texts about heritage seeds, vegetables or fruit. The texts include tweets, academic journal articles, newspaper articles, press releases, food packaging, menus, TV and radio programmes, websites and posters. They are produced by a broad range of organisations or types of author, including genebanks, lifestyle journalists and activist groups (see Wincott, 2015 for an introduction and background to these). The timeframe of the texts spans the late 1990s to the present day, but leans heavily to texts produced in the last five years due to the rapid proliferation of heritage vegetable discourse in the UK in particular during this time.

The database represents a useful resource for discourse analysis, but the heterogeneous nature of the texts means it cannot be used to generate quantifiable data. Expressions of the discourse produced as texts, particularly online, are inevitably represented more heavily than other discursive instances, so lifestyle journalism is represented by a large number of texts, while longstanding activities such as the storage of germplasm in a gene bank may count only as a handful of examples. It offers the chance however to examine the characteristics of heritage-as-treasure and traces the ways it may change as it is employed across the network of interest groups, from gene banks to retailers. And thus to ask what work it does within heritage crop discourse, and in whose interest.

\section{The value of heritage: seeds and genes as 'treasure'}

Uses of the word 'treasure' itself are numerous. The UN FAO calls genetic diversity a 'treasure chest' of valuable traits under threat (FAO, 2010, p. 184), for example. The phrase "an invaluable treasure for mankind' is used in numerous agricultural science publications (eg Guteva, Varbanova, \& Shamov, 1998; Kumari et al., 2016; Vetelainen, Negri, \& Maxted, 2009). Publicity for a gene sequencing project at the John Innes Centre genebank refers to the collection as 'a treasure trove'. The idea of heritage as material 'treasure' is not always quite so explicit however, and can be built through layers of repeated imagery and the enrolment of materials. In the BBC report on Svalbard, mentioned at the start of this article, it is developed through the term 'precious cargo' and through the many references to security, something which implies preciousness, as well as a threat to it. Thus concrete, steel and ice are engaged in the accomplishment of the treasure metaphor. 
A National Trust webpage (2015) demonstrates the way these layers are built up. It describes wholesale destruction of orchards, and two heritage enthusiasts rescuing wood with which to found a new heritage 'Mother Orchard' on the NT's Cotehele estate in south west England:

Each parish or farm once boasted its own small collection of distinct apples, whose names and uses were carefully guarded and handed down over the years. Generations of families tended orchards. Local traditions were tied to the orchard calendar. Sadly, [...] these living windows on the region's cultural heritage had all but vanished by the late 1970s. [...] Precious details and scion wood for many varieties were found in the nick of time. In one case [conservationists] snatched unburned twigs from a bonfire after new homeowners chopped down a rare tree.

Here the apple wood snatched from the bonfire is 'precious' and its unthinking almostdestruction a kind of vandalism, the almost-loss heightening the sense of value. The theme of loss enhances both the idea of value and the need for safeguarding. I will return to the significance of safeguarding in the next section. In the example above, as in many others, the emphasis on great age and continuity of the heritage varieties also helps to intensify the idea of preciousness in heritage vegetable texts (Wincott, 2015, p. 577).

The treasure motif appears in the presentation of Sainsbury's supermarket Taste the Difference range heritage tomatoes. Red, orange and yellow baby tomatoes, visible through the cellophane wrapping, are labelled 'Heritage Jewels'. This is an unusual use of it in retail and lifestyle texts, however. Where it does occur, it seems to be drawing attention to the colours of heritage vegetables, more varied and vivid than non-heritage types, an effect sometimes heightened in the case of root crops by contrast with the mud they emerge from. For example, a Telegraph article (Hart, 2011) features a grower supplying Marks and Spencer stores with different coloured heritage carrots and likens them to precious metals:

Clouds the colour of slate are massing in the east, but the carrots pulled from the ground, and cleaned in a silver bucket carried for that purpose by a Jeevesian agronomist named Peter (a consultant who is developing heritage varieties of carrot), are bathed in winter light and glow like red and yellow gold.

Journalists, like marketing copywriters engaged to sell premium tomatoes, must be creative in their use of language, must draw attention to a phenomenon or a product, and tempt the reader or consumer. Yet scientists writing for intergovernmental organisations and scientific journals also turn to the treasure metaphor frequently, despite the fact it is not drawn from the scientific frame of reference. These authors do not stand to benefit from the sale of heritage vegetables, and in the next section I consider how the framing of heritage crops as 'treasure' is nonetheless productive for these interest groups, because of the way it structures the idea of the value of heritage and how it ought to be preserved.

\section{Guardians of vegetable heritage}

The concept 'treasure' brings a set of other concepts in its wake, such as wealth, profit and the vault. Science magazine (Gewin, 2015), reporting on a new gene bank consortium called DivSeek, headlines the piece 'DivSeek aims to mine the genetic treasure in seed bank vaults'. The concept of heritage as treasure frames the entire article, where gene banks around the world store 'wealth' which can, through the DivSeek initiative to share information between gene banks, finally be 'capitalised on'. The 'Visit Wakehurst Millennium Seed Bank'2 webpage on Kew Royal Botanic Gardens' website celebrates its official opening by

\footnotetext{
${ }^{2}$ Kew Royal Botanic Gardens preserves wild plant varieties in its Wakehurst Millennium
} 
Prince Charles using the same analogy:

His Royal Highness Prince Charles officially opened the Millennium Seed Bank (MSB) in 2000,

describing it as "a gold reserve ... a place where this reserve currency, in this case life itself, is stored."

What these examples demonstrate is the way the treasure metaphor goes beyond a creative use of language to structure ideas about what can and should be done with these resources. As the seeds, plants or their genes are likened to treasure, so the places they are housed are likened to banks, vaults or treasuries. They are 'mined' like a raw natural resource, rather than created by human culture. And as well as being kept safe they are associated with the idea of wealth and profit.

The idea of 'banking' can refer to collective saving and sharing of seeds, from which members may draw seed for planting, and the database contains some mention of these kinds of community seed bank schemes, or seed saving networks, which have been established in many developing countries by farmers and in richer parts of the world by home growers since the 1980s (Vernooy, Shrestha, \& Sthapit, 2015). These 'banks' are very different to the secure vaults mostly referred to using the treasure-bank pairing. Genebanks are special spaces of expert conservation. Not all are perhaps quite as high security as the Svalbard seed vault, with its remote location and steel security doors. But they are closed from public access, managed by specialist professionals. The crop research organisation CGIAR (1996) concludes that germplasm, that 'invaluable treasure for mankind', 'should be studied, maintained and stored in living condition in order to be used now and in the future', emphasising static maintenance and prioritising study, rather than active growing, selection or consumption.

Vavilov, a Russian botanist, is in crop science texts widely credited with starting the preservation of crop heritage. His ambition was:

to gather the varietal diversity from all over the world, bring it to order, turn the Department into the treasury of all crops and other floras, and launch the publishing of "Flora Culta", the botanical and geographical study of all cultivated plants. (quoted in Loskutov, 1999, p. 18)

Vavilov, and to a lesser degree US agronomists Harry and Jack Harlan, are characters in a kind of founding myth of the gene banking sector or 'genetic resources movement' (Westengen, Jeppson, \& Guarino, 2013. See also Qualset, 1997 and the BBC Radio 4 series Plants: From Roots to Riches, 2014). In such accounts, Vavilov and others are portrayed as far-sighted pioneers, scouring the world for genes of potential value. That value is only considered realised when samples are brought home for safe storage. Here they can be understood through scientific ordering and classification (Hall, 2005, p. 24) and their worth expressed in crop breeding programmes. They are in other words considered a little like metal ore or uncut diamonds, worth nothing until they are processed by humans. Yet of course these crop varieties have already been part of human economic and cultural activity, they have been selectively bred by many generations of farmers or small-holders. The skill and work of these farmers is made invisible in the metaphor or mining for precious materials.

The most recent UN FAO Report on the State of the Worlds Plant Genetic Resources for Food and Agriculture estimated that the total number of 'accessions' conserved in closed collections worldwide had increased by approximately 20 percent since its first report in 1996, totalling around 7.4 million, in 2,500 genebanks and botanical gardens (FAO, 2010, p.

Seed Bank, among them food plants and crop wild relatives. 
$x x i)$. This enormous investment in genebanking as the solution to change or loss of crop diversity has been enabled, and to some extent shaped, by the treasure metaphor. Although there are other ways in which heritage value and guardianship are conceptualised-and I will touch on these later in this section-the prevalence of the treasure motif means it has to be considered as an important part of what it has come to mean for people to think about the food system through the lens of heritage. In recent years however, there has been a great growth of heritage crop conservation by organisations running heritage gardens and orchards. The funding model for these undertakings enrols different groups of people in the project of conservation, meaning the conservation sites cannot be completely closed to the wider public. This raises the question of whether these gardens challenge the treasure-inthe-vault metaphor.

While genebank funding enables closed storage of 'germplasm', accessible only to researchers, heritage gardens are funded through a combination of membership, donations, sales and entry fees, all of which necessitate offering some form of access to the general public. The National Trust runs many historic kitchen gardens, displaying heritage fruit and vegetables. The Heritage Seed Library (HSL)—often glossed in the media as a body founded to 'rescue our vegetable treasures' (Evans, 2007), or 'where treasured plant varieties are housed' (BBC Gardeners' Question Time, 15 Jan 2012)—has a visitor centre at its parent organisation, Garden Organic's show garden. It offers a membership scheme, and members receive six heritage varieties to grow at home. Though the conservation discourse of these membership bodies features some public engagement, the idea they are safeguarding treasure is still central to the discourse of heritage conservation at these sites. The idea of the bank vault is not used, but the safe keeping of treasure is enacted in other ways, primarily the development and display of collections.

Forming a collection is a crop heritage guardianship activity (Wincott, 2015, p. 579) common to genebanks and heritage organisations. Taking the frame of reference of the museum or art gallery, the discourse of the heritage vegetable collection develops a kind of heritage that is potentially mundane-relating to food and farming, and easily reproduced by anyone who can buy or save seed-making into something approaching official national treasure. The seeds and plants in these collections are rarely unique themselves, but the organisations work hard to assert the uniqueness and importance of their collection. Thus the collection becomes something precious in itself. The John Innes Centre's website boasts it is 'custodian of a number of key germplasm collections' which 'are the subject of research in their own right'. The National Trust's Knightshayes Court claims to offer 'a unique chance to see a vast collection of crops which are now almost extinct', and its Clumber Park boasts ' 130 varieties of rhubarb, the largest collection in the UK' and ' 72 varieties of apple that have been awarded National Plant Collection status'. The idea of national status is popular. The Royal Horticultural Society asserts that it holds 'the national collection of rhubarb', while Brogdale has 'the National Fruit Collection', for example. The prefix signals official institutional status but it also represents the staking of a claim to be the to be the single entity entitled to safeguard these collections over that particular territory - in effect, discursively bonding mutable forms of heritage to specific collections of material remains, and hence specific heritage sites.

The spaces of vegetable heritage management tend to be represented in promotional materials as grand and imposing, illustrated by images of neat rows of vegetables, in large, well-tended grounds, bordered by high walls, often with the country house in the 
background. The garden, with its living organisms, growing and always changing, appears ordered and static. In common with images of historic sites in general, there are rarely visitors or gardeners to be seen in these immaculate spaces (Waterton, 2010). The gardens are laid out not only in order to direct and classify the plants but to direct the visitor, using walls, paths, labels and sign posts. The visual and spatial grammar is familiar from the museum, art gallery or heritage site, an idea reinforced by the advertisement of opening hours, the entry price and the shop, where souvenirs can be purchased. In other words, it is a form of conservation and display already associated with the reverent viewing of national treasures. Illustrations in texts about seed banks also tend to feature very few people, preferring images of regimented rows of containers or the buildings that house them, a decontextualising familiar from museums. This aesthetic stems from and reproduces a focus on the materials of heritage, at the expense of telling stories about its relationships or its social and cultural meanings. This is a reductionism Carolan associates with biotech genebanking (Carolan 2007, p. 743) but which extends to botanic or heritage gardens.

A pre-occupation with impending loss is central to heritage discourse generally (Lowenthal, 1998, p. 26; Samuel, 1994, p. 221) and highlighting risk is important in justifying any heritage project, and crops are no exception. That these crops are at risk is often repeated, but blame is not ascribed. To highlight loss while not mentioning the human politics of crop breeding and food production-and the role of crop science itself in the loss of heritage-requires some techniques of misdirection. Texts frequently use of the passive form (diversity is at risk, landraces have all but disappeared, species are being eroded) and focus on the consequences of 'genetic erosion' - vulnerability to pests, disease and global warming. These reminders serve to heighten a sense of danger in themselves and again shift the focus of attention from specific groups of people who have actively reduced crop diversity over the past 100 years (crop geneticists, bio-tech companies) to more generalised non-human threats (microbes, insects, the weather).

Risk is also implied in the fetishizing of the security provided by secure vaults, particularly in texts about Svalbard. An FAO report enthuses about Svalbard's security features: 'Located in the permafrost, 130 metres into a mountainside on an island just $800 \mathrm{~km}$ from the North Pole, SGSV provides unprecedented levels of physical security.' (2010, p. 71). On the Crop Trust website a page headed 'what we do' describes the building and its setting vividly:

Deep inside a mountain on a remote island in the Svalbard archipelago, halfway between mainland Norway and the North Pole, lies the Svalbard Global Seed Vault. It is a fail-safe, state-of-the-art seed storage facility, built to stand the test of time - and of natural or manmade disasters.

The ideas of risk, of the inherent preciousness of heritage crops and their storage in secure vaults are all mutually reinforcing aspects of heritage-as-treasure discourse. The closed loop appears so logical, so seamless and so inevitable, that it disguises very effectively its effect of removing the seeds and plants from a wider constituency of growers, in effect privatising them, on the grounds of security. It also distracts from the complete failure to be frank about the reasons for 'genetic erosion'.

\section{Challenges to the treasure vault metaphor}

The particular nature of the treasure-in-the-vault model of crop conservation can be more clearly seen when it is compared with alternative conceptualisations of the value of heritage 
crops. Examples can be found in the lifestyle media, food packaging and the promotional materials of the growing number of restaurants, seed suppliers and supermarkets selling heritage produce or seeds. Here, a consumerist strand of heritage crop discourse emphasises the sensory pleasures to be found in heritage foods, because of their vivid and varied shapes and colours, the increased choice they represent, their reputedly superior taste and even the 'warm fuzzy feeling' (HSL 'adopt a veg' webpage, 2014) of connecting with and helping to rescue food heritage.

Reports, newsletters and posters produced by activist groups also offer the chance to see another framing of heritage value. They tend to emphasise the value of heritage practices over heritage materials or experiences - the practices of growing and saving seed from traditional varieties. The right to cultivate and share traditional varieties so is often framed as the heritage at stake, as much as the varieties themselves, and the heritage is said to be threatened by the increasing hold of the global biotech corporations over food production. It is the texts produced by activist groups that produce the most explicit attacks on the use of secure vaults to safeguard seeds and genes. La Via Campesina, which campaigns for smallscale agriculture, characterizes the peasant farmer as a last line of defence in the fight to protect heritage, and genebanks a challenge to heritage conservation to be overcome:

If the know-how of farmers and peasants in selecting and conserving seeds disappears as older people pass away, our children will be left at the mercy of multinationals. If small-scale practitioners do not, starting today, go and retrieve from still accessible refrigerated banks the seeds of their parents which are required for new selections, then these seeds will no longer be available tomorrow. (La Via Campesina, 2013)

Elsewhere in the same booklet, Svalbard's 'precious cargo' of the BBC report is derided as 'frozen corpses' and the group repeatedly undermines the genebanks' claims to act on behalf of humanity by linking them to corporate interests:

The industry cannot produce its "improved" seeds without drawing on the heritage of peasant seeds. This is why it has mobilized states to collect these seeds - at the same time that it works towards prohibiting them in the fields - and to lock them up in gene banks made available to the industry.

In these examples, a battle to define gene banking is happening as the same facilities are framed very differently to the sector's own texts. The clinical precision and great security of genebanking in Svalbard-led narratives is associated here with death and imprisonment. Blame for genetic erosion is not side-stepped here.

The literature produced by one Scottish community group, the Fife Diet, shows that the treasure metaphor is not inevitably used to cultivate a secure and privatised form of guardianship. Their heritage apple booklet The Apple Hunter's Handbook (Walker \& Elphee, 2014), is subtitled 'Find Scotland's Lost Treasure' and emerges from a heritage fruit project they named 'the Silver Bough'. In the webpages about the Silver Bough and Seed Kist projects, they describe Scottish fruit and vegetable heritage as forgotten 'wealth' and 'treasure', which, through their work, are being rediscovered:

The Seed Kist is a treasure chest full of seeds. It is a symbol for the wealth and diversity of the crops that grow in Scotland. [...] we should look beyond the chips and begin to rediscover the hundreds of unique and unsung Scottish fruit and veg varieties, and reclaim them as part of our culture. (Seed Kist webpage)

Although the organisations says it aims to 'set up a national collection of Scotland's unique heritage varieties', its descriptions of the collection and how it is formed are very different to the large heritage institutions and gene banks. They frame fruit and vegetable heritage as a cultural asset, linked with food traditions and legends, rather than a material asset for professional crop breeding. The group's webpage updates on the Seed Kist Tour show the 
openness of their conservation model to the practices and knowledge of others:

We think everyone should make their own Seed Kist - each region of Scotland, each glen, each community garden or croft - and appoint a keeper of the kist who will make sure that the seeds of all the most valued crops are gathered in each year to restock the collection.

The collection work of the group seems to represent an attempt at conservation through awareness raising and the mobilising of a dispersed network of local activists, who will act collectively to safeguard heritage. In place of an emphasis on loss as a kind of extinction, as is more common in the texts produced by gene banks and heritage institutions, the Fife Diet texts speak about lost heritage as if it were buried treasure - ready to be unearthed by the motivated consumer or grower. The Fife diet texts show that the idea of 'treasure' itself is less important than how it is developed.

\section{The consequences of the treasure metaphor}

The treasure-at-risk motif may seem at first glance like a useful tool to communicate the value of genetic diversity or of crop heritage. But it shapes that value and constrains understanding of what heritage is for, who it is for and what ought to be done with it. It emphasises the materiality of plants, their seeds or genes, thus establishing them as something that can be owned. This supports the development of the 'collection', a strategy by which institutions make seeds or plants into unique and irreplaceable 'treasures', and hold them in trust for future generations. A range of material entities from white coats to an arctic glacier are then enrolled in the stabilisation of this particular understanding of heritage as treasure and its protection as synonymous with secure custodianship and in some cases, reverent display and public viewing. In other words, as well as bonding the abstract notion of heritage to material accessions, the treasure metaphor also helps to bond heritage to discrete sites of guardianship, always under expert control. This is despite the continued existence of the same varieties in collections, farms and gardens elsewhere. The treasure in the vault narrative encourages the idea that this heritage is only meaningful in the secure collection, where its raw potential can be actualised by expert study. The associations of 'treasure' with resources 'mined' from the ground helps erase the prehistory of these varieties on farms and in gardens. It thus also erases the work and creativity of other people, who had already worked on this 'treasury', using selective breeding on plants, giving them different meanings, based in traditions of food production and consumption.

The collecting and study of heritage specimens is an exercise of the symbolic power to order and give meaning to the contested field of heritage crop discourses (Hall, 2005, p. 24), taking crop varieties from these other contexts and stripping them of their existing meanings and value, assigning them new ones - conservationists' treasures. Guardianship of a collection thus affords discursive control over the materials and meanings of heritage crops. The association of treasure with monetary wealth is also brought into play. When collections are kept as a reserve, ready to be 'capitalised on' by the institutions who invest in them. As well as securing these resources away from the general public (Carolan 2007, pp. 747), framing heritage crops as treasure also paves the way for their use in profit-making activity and the securing of rights of collection owners through plant breeder's rights and patents.

The dominant idea of treasure employed in institutional, expert-led crop heritage discourse generally avoids being too literal about the potential to translate natural 'treasury' into financial wealth though. Treasure is generally envisioned as a wealth of humankind, 
used in projects of education and advancement of human civilisation, to feed the world. The story of heritage crops told by conservation bodies is one apparently without discord or difference of interest, where experts hold safe 'an invaluable heritage for mankind', on behalf of us all (Krasteva, Stoilova, Varbanova, \& Neykov, 2009, p. 53). The risks to crop heritage treasure and solutions for preservation are all understood to exist entirely within and for the use of the professional agricultural sector or the field of heritage conservation. The ethos of heritage protection as a service to humankind and future generations obfuscates the effective privatisation of these resources in secure genebanks, and corporate use of those genebank resources. It also glosses over the role that expert plant breeding has played in reducing genetic diversity, in other words, threatening the very treasures it aims to protect.

The treasure metaphor matters because of its uses in establishing and justifying the power of some interest groups over resources for food and agriculture. It is widely understood that home gardens, small holdings and habitats of crop wild relatives are vital reservoirs of genetic diversity (Bailey, Eyzaguirre, \& Maggioni, 2009; Hopkins \& Maxted, 2011, p. 27; Nazarea, 2005, 2006), and that diversity develops in the field, through traditional crop selection, rather than professional crop breeding programmes, which themselves reduce diversity in order to enable a more predictable crop, given certain inputs (Kell et al., 2009, p. 16; Vetelainen et al., 2009, p. 6). Yet around the world resources continue to be devoted to storing small quantities of seed at great cost in seed banks and heritage gardens and through government funding, charitable donations or purchases, the general population is called on to support these heritage conservation works.

Logically, then, the emphasis on preciousness and precariousness must be questioned. Declension narratives and the idea of the precariousness of precious remains from the past are so ubiquitous in both heritage discourse and environmental discourse generally that this is not an easy change to make. Yet the non-institutional discourse demonstrate that alternatives are available and becoming more widespread in places like the UK, where the treasure-in-the-vault conceptualisation of crop heritage faces increasing discursive pressure as consumer discourse in particular continues to grow (Food and Environment Research Agency, 2009; Horticultural Trades Association, 2010). It is an interesting development of crop heritage discourse that the greatest pressure on the privatisation of heritage resources may come not from public sector guardianship, but commercialisation.

\section{References}

Bailey A, Eyzaguirre PB and Maggioni L (2009) Crop Genetic Resources in European Home Gardens: Proceedings of a Workshop 3-4 October 2007, Llubljana. Rome: Biodiversity International.

BBC (2016) David Shukman reporting from Svalbard Global Seed Vault. News at Ten, 22 January.

BBC Radio 4 (2012) Gardeners' Question Time, 15 Jan. Somethin' Else for BBC.

BBC Radio 4 (2014) Plants: From Roots to Riches. 25-part series, 28 July-29 August.

Breen SD (2015) Saving seeds: the Svalbard Global Seed Vault, Native American seedsavers, and problems of property. Journal of Agriculture, Food Systems, and Community Development 5(2): 39-52.

Carolan M (2007) Saving seeds, saving culture: a case study of a heritage seed bank. Society and Natural Resources 20: 739-750.

CGIAR (Consultative Group for International Agricultural Research) (1996) 1971-1996: 25 Years of Food and Agriculture Improvement in Developing Countries. Available at: 
http://www.worldbank.org/html/cgiar/25years/gene.html (accessed 14 September 2017).

Evans P (2007) Seed sense. The Guardian, 18 July. Available at:

http://www.theguardian.com/society/2007/jul/18/conservation.food (accessed14

September 2017).

FAO (Food and Agriculture Organization) (2010) The Second Report on the State of the World's Plant Genetic Resources for Food and Agriculture. Rome: FAO. Available at: http://www.fao.org/docrep/013/i1500e/i1500e00.htm (accessed 14 September 2017).

Food and Environment Research Agency (2009) Conservation and Amateur Vegetable Varieties Directive 2009/145/EC. Available at:

http://archive.defra.gov.uk/corporate/consult/veg-variety/100804-veg-variety-condocpia.pdf (accessed 14 September 2017).

Foucault M (1972) The Archaeology of Knowledge, trans. Sheridan Smith AM. New York: Pantheon.

Foucault M (1977) Language, Counter-memory, Practice: Selected Essays and Interviews, trans. and ed. Bouchard D. Ithaca, NY: Cornell University Press.

Foucault M (1994 [1970]) The Order of Things: An Archaeology of the Human Sciences. New York: Vintage.

Fowler C and Mooney PR (1990) Shattering: Food, Politics and the Loss of Genetic Diversity. Tucson, AZ: University of Arizona Press.

Friis-Hansen E and Sthapit B (2000) Participatory Approaches to the Conservation and Use of Plant Genetic Resources. Rome: International Plant Genetic Resources Institute.

Gewin V (2015) 'DivSeek aims to mine the genetic treasure in seed bank vaults. Science Magazine, 9 January.

Graddy TG (2013) Regarding biocultural heritage: in situ political ecology of agricultural biodiversity in the Peruvian Andes. Agriculture and Human Values 30(4): 587-604.

Guteva Y, Varbanova K and Shamov D (1998) Enrichment of national collection of plant genetic resources with new germplasm. Agricultural Science 35: 791-795.

Hall S (2005) Whose heritage? Un-settling 'the heritage', re-imagining the post-nation. In: Littler J and Naidoo R (eds) The Politics of Heritage: The Legacies of 'Race'. Abingdon: Routledge, pp. 23-35.

Hart C (2011) Return to roots: heritage varieties of carrot. Telegraph, 16 November. Available at: http://www.telegraph.co.uk/foodanddrink/recipes/8891258/Return-to-rootsHeritage-varieties-of-carrot.html (accessed 14 September 2017).

Hopkins J and Maxted N (2011) Crop wild relatives: plant conservation for food security. Peterborough: Natural England. Available at: http://publications.naturalengland.org.uk/file/64058 (accessed 14 September 2017).

Horticultural Trades Association (2010) HTA GIM Market Update - All Things GO Drive Garden Market. Report based on market research.

HSL (Heritage Seed Library) (2014) Adopt a veg. Available at: http://www.adoptaveg.org.uk:80/

viewgifts.php (accessed 14 September 2017).

Jabs C (1984) The Heirloom Gardener. San Francisco: Sierra Club Books.

Jordan JA (2007) The heirloom tomato as cultural object: investigating taste and space. Sociologia Ruralis 47(1): 20-41.

Jordan JA (2015) Edible Memory: The Lure of Heirloom Tomatoes and Other Forgotten Foods. Chicago University of Chicago Press.

Kastler G, Onorati A and Brac B (2013) Seeds and peasant autonomy. In: Bellows A, Callenius C, Campeau X, Cedeño MA, Immink M, McNeely K et al. (eds) Right to Food and Nutrition Watch 2013: Alternatives and Resistance to Policies that Generate Hunger. Heidelberg: Brot für die Welt, FIAN International and ICCO Cooperation, pp. 47-53.

Kell SP, Maxted N, Astley D, Allender C, Ford-Lloyd BV and Contributors (2009) Vegetable Landrace Inventory of England and Wales. Available at: www.grfa.org.uk/media_files/

publications_plant/veg_Ir_inventory_england_and_wales.pdf (accessed 14 September 2017).

Krasteva L, Stoilova T, Varbanova K and Neykov S (2009) Bulgarian Landrace Inventory - 
significance and use. In: Veteläinen M, Negri V and Maxted N (eds) European Landraces: On-farm Conservation, Management and Use. Rome: International Plant Genetic

Resources Institute , pp. 53-68.

Kumari J, Kumar A, Bhatt KC, Mishra AK, Singh TP and Sharma RK (2016) Characterization of maize collections from Nagaland state of North Eastern Himalayan region. Plant Gene and Trait 7(12): 1-7.

La Via Campesina (2013) La Via Campesina: Our Seeds, Our Future. Notebook No. 6. Jakarta: La Via Campesina. Available at: https://www.slideshare.net/S7w4X/zwv110 (accessed 14 September 2017).

Laclau E and Mouffe C (2001) Hegemony and Socialist Strategy: Towards a Radical Democratic Politics, 2nd edn. London: Verso.

Latour B (1986) The powers of association. In: Law J (ed.) Power, Action and Belief: A New Sociology of Knowledge? London: Routledge and Kegan Paul, pp. 264-280.

Latour B (1991) Technology is society made durable. In: Law J (ed.) A Sociology of Monsters? Essays on Power, Technology and Domination. London: Routledge, pp. 103131.

Law J (1991) Power, discretion and strategy. In: Law J (ed.) A Sociology of Monsters? Essays on Power, Technology and Domination. London: Routledge, pp. 165-191.

Loskutov IG (1999) Vavilov and his Institute: A History of the World Collection of Plant Genetic Resources in Russia. Rome: International Plant Genetic Resources Institute.

Lowenthal D (1998) The Heritage Crusade and the Spoils of History. Cambridge: Cambridge University Press.

Mulvany P and Berger R (2002) Sustaining Agricultural Biodiversity. Produced for the Forum for Food Sovereignty by ETC Group, GRAIN, ITDG. Available at: http://practicalaction.org/docs/ia4/accessgenres.pdf (accessed September 2017).

National Trust (2012) Going Local: Annual Report 2011/12. Available at: http://www.nationaltrust.org.uk/about-us/annual-reports/ (accessed 14 September 2017).

National Trust (2015) Preserving Cornish heritage one apple at a time. Available at: http://www.nationaltrust.org.uk/article-1356393744760/ (accessed 14 September 2017).

Nazarea VD (1996) Fields of memories as everyday resistance. Cultural Survival Quarterly 20(1), Available at: https://www.culturalsurvival.org/publications/cultural-survivalquarterly/fields-memories-everyday-resistance (accessed 14 September 2017).

Nazarea VD (1998) Cultural Memory and Biodiversity. Tucson, AZ: University of Arizona Press.

Nazarea VD (2005) Heirloom Seeds and Their Keepers: Marginality and Memory in the Conservation of Biological Diversity. Tucson, AZ: University of Arizona Press.

Nazarea VD (2006) Local knowledge and memory in biodiversity conservation. Annual Review of Anthropology 35: 317-335.

Phillips C (2016) Saving More than Seeds: Practices and Politics of Seed Saving. London: Routledge.

Qualset CO (1997) Jack R. Harlan (1917-1998) - plant explorer, archaeobotanist, geneticist and plant breeder. In: Damania AB, Valkoun J, Willcox G and Qualset CO (eds) The Origins of Agriculture and Crop Domestication: Proceedings of the Harlan Symposium, ICARDA, Aleppo, Syria, 10-14 May.

Samuel R (2012 [1994]) Theatres of Memory: Past and Present in Contemporary Culture, 2nd edn. London: Verso.

Scarascia-Mugnozza GT and Perrino P (2002) The history of ex situ conservation and use of plant genetic resources. In: Engels JMM, Ramanatha Rao V, Brown AHD and Jackson MT (eds) Managing Plant Genetic Diversity. London: CABI Publishing, pp. 1-22.

Smith L (2006) Uses of Heritage. London: Routledge.

Vernooy R, Shrestha P and Sthapit B (eds) (2015) Community Seed Banks: Origins, Evolution and Prospects. Abingdon: Routledge.

Vetelainen M, Negri V and Maxted N (eds) (2009) European Landraces: On-farm Conservation, Management and Use. Rome: International Plant Genetic Resources Institute. 
Walker F and Elphee M (2014) The Apple Hunter's Handbook: Find Scotland's Lost Treasure. Available online at:

https://issuu.com/fifediet/docs/fifediet_silverbough_bookleta6_fort (accessed 14 September 2017).

Waterton $E$ (2010) Branding the past: the visual imagery of England's heritage. In: Waterton E and Watson S (eds) Culture, Heritage and Representation: Perspectives on Visuality and the Past. Farnham: Ashgate, pp. 155-172.

Westengen OT, Jeppson S and Guarino L (2013) Global ex-situ crop diversity conservation and the Svalbard Global Seed Vault: assessing the current status. PLoS One 8(5).

Wincott A (2015) Heritage in danger or mission accomplished? Diverging accounts of endangerment, conservation and 'heritage' vegetables in print and online. Food, Culture and Society 18(4): 569-588. 